\title{
Potential phenotypic plasticity within Simulium nigrimanum Macquart, 1838 (Diptera: Simuliidae) larvae
}

\author{
Ronaldo Figueiró ${ }^{* 1,2}$, Anderson Calvet ${ }^{3}$, Leonardo Henrique Gil-Azevedo ${ }^{4}$, Ricardo Ferreira \\ Monteiro $^{5}$, Marilza Maia-Herzog ${ }^{3}$
}

\section{Edited by}

Juan Carlos Salcedo-Reyes

salcedo.juan@javeriana.edu.co

1. Fundação Centro Universitário Estadual da Zona Oeste (UEZO), Unidade de Biologia, Av. Manuel Caldeira de Alvarenga, 1203, Rio de Janeiro/RJ, Brazil, 23070-220

2. Centro Universitário de Volta Redonda (UniFOA), Av. Paulo Erlei Abrantes, 1325, Volta Redonda/RJ, Brazil

3. Fundação Oswaldo Cruz (FIOCruz), Laboratório de Simulídeos e Oncocercose, Av. Brasil, 4365, Rio de Janeiro/RJ, Brazil, 21041-361

4. Universidade Federal do Rio de Janeiro (UFRJ),Departamento de Entomologia, Museu Nacional, Quinta da Boa Vista, Av. Carlos Chagas Filho, 373, Rio de Janeiro/RJ, Brazil, 20940-040

5. Universidade Federal do Rio de Janeiro (UFRJ), Departamento de Ecologia, Laboratório de Ecologia de Insetos, Rio de Janeiro, RJ, Brazil, 21941-912

*ronaldofigueiro@gmail.com

Received: 07-05-2020

Accepted: 23-02-2021

Published online: 04-08-2021

Citation: Figueiró R, Calvet A, Gil-Azevedo LH, Ferreira Monteiro R, Maia-Herzog M. Potential phenotypic plasticity within Simulium nigrimanum Macquart, 1838 (Diptera: Simuliidae) larvae, Universitas Scientiarum, 26(2): 217-227, 2021.

doi: 10.11144/Javeriana.SC26-2.pppw

Funding: Programa de Pós-graduação em Biodiversidade e Saúde / Fundação Oswaldo Cruz at Laboratório de Simulídeos e Oncocercose; the CNPq, FAPERJ, and FIOCRUZ.

Electronic supplementary material: n.a.

\begin{abstract}
Black fly larvae (Diptera: Simuliidae) are suspension filter-feeders which strongly depend on water velocity for proper feeding. Black fly species feature different microhabitat preferences. Studies of Holarctic black fly larvae revealed their phenotypic plasticity in response to water current velocity variation, but such studies have been rarely undertaken with Neotropical black flies. The current work presents results on the phenotypic plasticity of the black fly species Simulium nigrimanum Macquart. Twelve last instar larvae, sampled from the Brazilian Cerrado, were photographed under a stereoscopic microscope and measured using the CMEIAS Image tool software. Linear regressions with water velocity as the independent variable were performed, indicating that while body size and anal disk diameter correlated positively with water velocity, labral fan length correlated negatively. The observed relationships between water velocity and labral fan length and anal disk diameter were consistent with the literature, while the pattern of body size variation partially corroborated previous studies. The present work results suggest that potential phenotypic plasticity can be observed in black fly larvae within one population distributed in different microhabitats of the same stream section, as opposed to previous reports implying that such variation is only found among population from different streams.
\end{abstract}

Keywords: Black fly; labral fans; anal disk; water current.

\section{Introduction}

Although black flies (Diptera: Simuliidae) are a cosmopolitan insect family with world wide geographic range, their local occurrence is limited by suitable microhabitat characteristics allowing immature filter feeding black fly larvae to breed develop [1]. Black fly populations are regulated by biotic and abiotic factors, the former being competition, predation, and disease [2, 3]; and the latter involving to microhabitat features such as substrate and water velocity $[4,5,6,7]$. Black flies are key organisms in lotic systems, regarded as ecosystem engineers. This is due to the silk their larvae produce essentially altering the microhabitat enabling other organisms to fixate more easily in the substrate. The water velocity influences their ability to capture organic matter in suspension in the water column [7], and due to their ability to convert smaller particles of organic matter into larger nutritive fecal pellets of organic matter because of their low digestive efficiency they are considered key organisms in the boreal biome [7, 8], and also the adults of some species are important disease vectors $[9,10,11]$.

Black fly larvae usually reach their pupal stage on the same microhabitat they spent their last instar larval stage [7]. 
Ecological theory suggests that niche partitioning through differential use of resources is a key factor to diversity, as it promotes the local coexistence of ecologically similar black fly species [12]. This coexistence can be reached due to differential adaptations to microhabitat aspects; Nearctic and Palearctic black fly larvae are known to show different labral fan morphologies in relation to species level preferences $[13,14]$. Likewise, body size is strongly related to water velocity and food availability $[15,16]$. Even though these morphological relations are often studied in Holarctic black fly larvae, in their Neotropical relatives, these phenomena have rarely been approached [17].

In addition to its role as potential vector of the onchocerciasis, literature has suggested that the black fly species Simulium nigrimanum Macquart 1838 is potentially related to the skin condition known as Pemphigus Foliaceus [18, 19]. This makes the investigation of the bionomic and ecological traits of this species extremely relevant to public health. Simulium nigrimanum is widely distributed in South America [18, 19] and their larvae live associated to rocky substrates on small streams with dense canopy cover [11]. In this paper we investigate the relationships among S. nigrimanum morphological traits and water velocity; evaluating if these traits are correlated to this abiotic factor and among themselves.

\section{Materials and Methods}

\subsection{Study area}

The larva used in this study were originally sampled in from the Córrego do Mato (S12 $39^{\prime} 33.0^{\prime \prime}$, W48 $18^{\prime} 27.3^{\prime \prime}$ ), which is a small stream shaded by a dense canopy cover located in the Brazilian Cerrado from the state of Tocantins in northern Brazil [11]. The Cerrado is a savanna biome which presents a typical vegetation consisting of grasses and trees that do not provide a close canopy cover, due to the small size and low density of its trees, with the exception of the gallery forests, which are the riparian vegetation of this biome.

\subsection{Larvae sampling and identification}

Black fly larvae of later instars were sampled by hand during six campaigns on alternate months from October 2004 to August 2005. A $15 \mathrm{~m}$ stream section had 15 quadrats $(30 \mathrm{~cm} \times 30 \mathrm{~cm})$ sampled during each campaign.

Larvae were fixed in $70 \%$ ethanol and later sorted according to morphotype in the laboratory. Last instar specimens were dissected and identified using the taxonomic literature $[20,21]$ and direct comparison with pupae collected in the sites and with the material deposited at the Laboratório de Simulídeos e Oncocercose/Instituto Oswaldo Cruz (LSO-IOC).

Twelve last instar individuals of S. nigrimanum were then separated for use in the present study. Larvae were then photographed in a stereoscopic microscope equipped with a digital camera and later measured with the use of CMEIAS software [22]. The decision to analyze only last instar larvae was made, compromising total sample size, to avoid any potential bias from measuring different stage larvae, which may still be prone to drift and morphological structure growth. 


\subsection{Larval measurements and statistical analyses}

Each larva had its anal disk diameter, body length, and labral fan length measured according to the methodology described in Figueiró et al. [17] (Fig. 1). Whereas in this aforementioned study three different populations of Simulium subpallium Lutz 1909 from different lotic systems had their morphological traits compared, the present study assessed phenotypic plasticity within the same $S$. nigrimanum population investigating the patterns of variation within a single lotic system. All statistics and graphics were performed using PAST 4.3. These measures and the water velocities had their normality investigated using the Lilliefors test, and as all distributions were normal correlations among them and the water velocity were determined using the Pearson correlation coefficient. These morphological measures then were used as dependent variables in linear regressions in which the independent variable was the water velocity, which was measured in the field through the head rod method $[23,11]$.

\section{Results and Discussion}

A total of 430 S. nigrimanum larvae were collected, from which 15 were last instar larvae. Three of these 15 specimens were dissected in order to confirm species identity and the remaining larvae were measured (Table 1). All variables were significantly correlated (Table 2). Linear regressions indicated that water velocity correlated positively with anal disk diameter $(p<0.01$, $\left.r^{2}=0.73\right)$ and body length $\left(p<0.05, r^{2}=0.42\right)$ and negatively with labral fan length $\left(p<0.01, r^{2}=0.69\right)$ (Fig. 2).

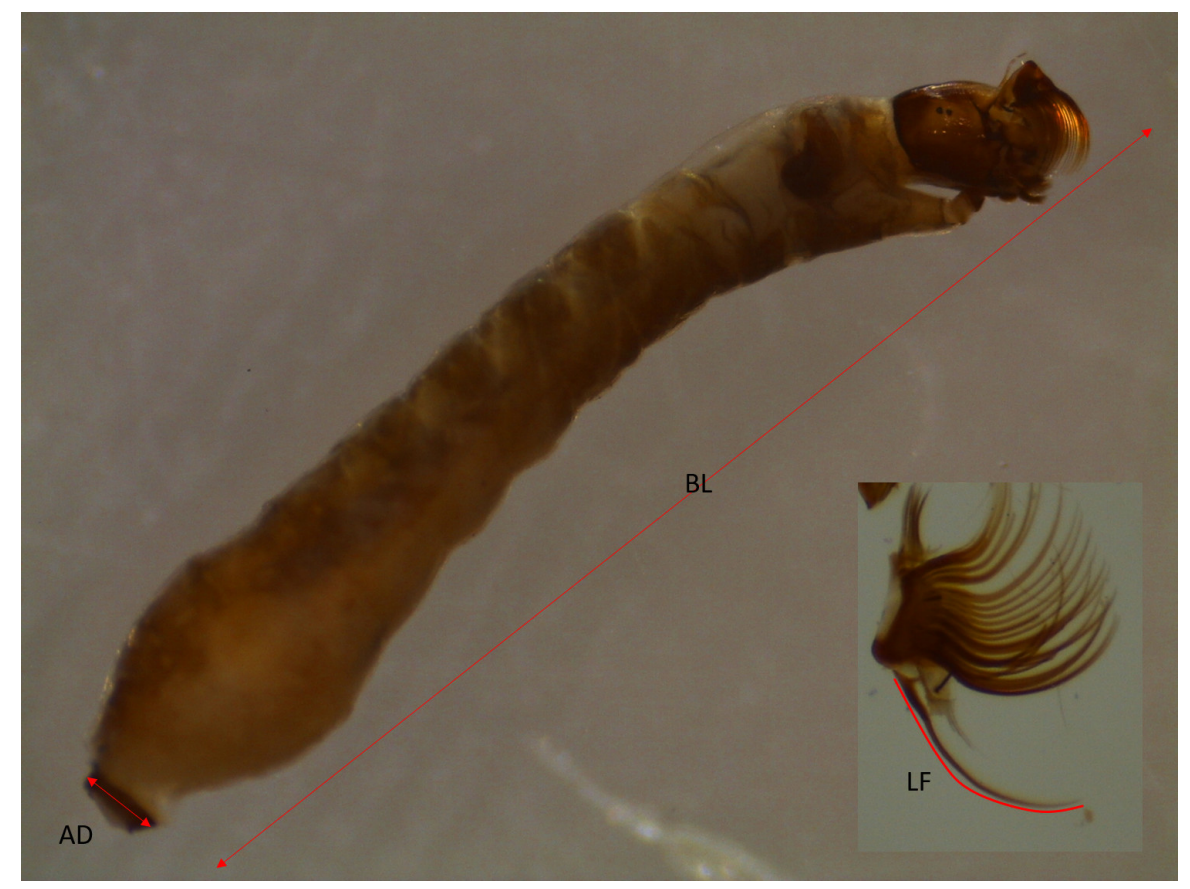

Figure 1. Measurements of black fly larvae morphology taken using CMEIAS: Anal disk diameter (AD), Body length (BL), and Labral Fan Length (LF). 
Table 1. Larval measurements and water velocity from which each specimen was collected.

\begin{tabular}{ccccc}
\hline Specimens & velocity & Anal disc diameter & body length & labral fan length \\
\hline 1 & 0.828674 & 0.04 & 0.58 & 0.05 \\
2 & 0.828674 & 0.04 & 0.57 & 0.05 \\
3 & 0.828674 & 0.04 & 0.57 & 0.04 \\
4 & 0.828674 & 0.03 & 0.59 & 0.06 \\
5 & 0.828674 & 0.03 & 0.62 & 0.05 \\
6 & 0.885889 & 0.05 & 0.71 & 0.04 \\
7 & 0.885889 & 0.05 & 0.65 & 0.04 \\
8 & 0.990454 & 0.05 & 0.65 & 0.04 \\
9 & 0.990454 & 0.05 & 0.67 & 0.04 \\
10 & 1.252837 & 0.06 & 0.68 & 0.03 \\
11 & 0.990454 & 0.04 & 0.67 & 0.03 \\
12 & 1.252837 & 0.07 & 0.68 & 0.02 \\
\hline
\end{tabular}

The labral fan patterns were consistent with previous studies in the literature on Holarctic species, with smaller labral fans selected in faster water flow velocities due to the decrease in the cost of drag $[15,16,24]$, however the observed body size variation pattern differed from that in these studies in which small larvae were observed in streams with the highest water flow velocities [15].

This divergence of the pattern of body size correlation to water velocity can be attributed to the range of water velocities sampled $\left(0.82 \mathrm{~m} \mathrm{~s}^{-1}\right.$ to $\left.1.25 \mathrm{~m} \mathrm{~s}^{-1}\right)$. Zhang \& Malmqvist [15] found that maximum body sizes were observed at moderate velocities with size decaying at faster velocities or, as suggested by Lucas \& Hunter [24], due to food availability. The abundance of food can also influence morphological traits in the case of optimal conditions for this species being found on faster flows.

The anal disk diameter was consistent with the pattern observed for S, subpallidum Lutz, 1910 larvae [17], with larger diameters observed at higher water flow velocities, probably due to these diameters accommodating more hooks or more robust hook structures that allow larvae to resist drag.

Table 2. Correlations between the morphological characteristics of Simulium nigrimanum larvae (Pearson's correlation coefficient). All correlations were significant.

\begin{tabular}{lllll}
\hline & Water flow velocity & $\begin{array}{l}\text { Anal disk } \\
\text { diameter }\end{array}$ & Body length & $\begin{array}{l}\text { Labral fan } \\
\text { length }\end{array}$ \\
\hline Water flow velocity & - & 0.85388 & 0.64891 & -0.83242 \\
Anal disk diameter & 0.85388 & - & 0.66033 & -0.83449 \\
Body length & 0.064891 & 0.66033 & - & -0.681 \\
Labral fan length & -0.83242 & -0.83449 & -0.681 & - \\
\hline
\end{tabular}



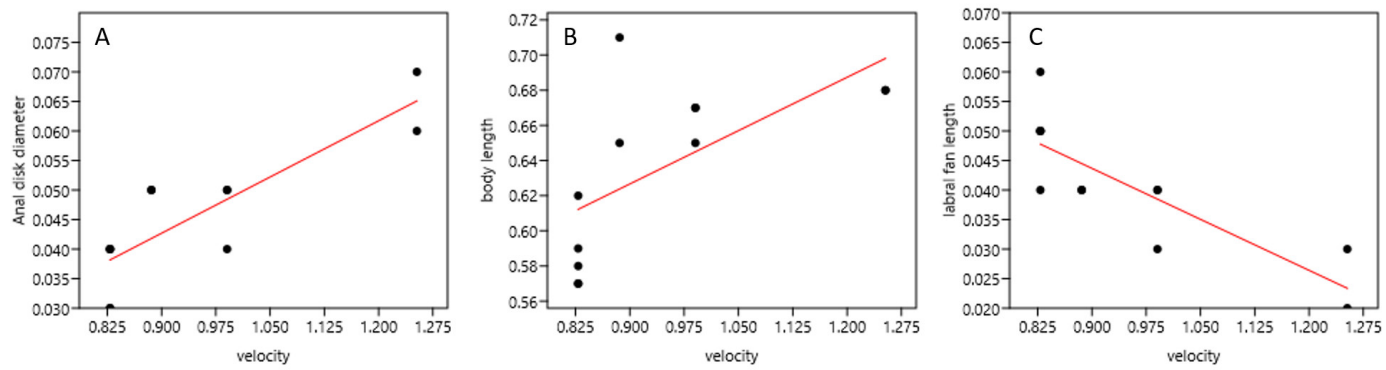

Figure 2. Linear regression of (A) water velocity versus anal disk diameter, showing a positive correlation $(p<0.01$, $\left.r^{2}=0.73\right)$; (B) water velocity versus body length, showing that larger larvae were associated to faster velocities $\left(p<0.05, r^{2}=0.42\right)$; and (C) water velocity versus labral fan length being negatively correlated $(p<0.01$, $\left.r^{2}=0.69\right)$.

\section{Conclusions}

These results suggest that potential phenotypic plasticity can be observed in black fly larvae within one population distributed through different microhabitats of a stream section, and this also represents the first data regarding $S$. nigrimanum phenotypic plasticity in response to microhabitat features. This data allows for a better comprehension of the spatial distribution of S. nigrimanum, which is considered a potential vector of the Onchocerciasis. The patterns observed in this study also suggest that although some of the trends observed in Neartic and Paleartic black fly larvae may be similar to those of Neotropical black flies, possibly some traits show markedly different patterns in the Neotropics.

\section{Acknowledgements}

The present work was funded via a Postdoctoral grant to Figueiró R. by Programa de Pósgraduação em Biodiversidade e Saúde / Fundação Oswaldo Cruz at Laboratório de Simulídeos e Oncocercose. The authors thank CNPq, FAPERJ, and FIOCRUZ for the financial support and the staff of Laboratório de Simulídeos e Oncocercose for all their support particularly with data collection and species identification.

\section{Conflict of interest}

The authors declare no conflict of interest.

\section{References}

[1] Currie DC, Adler PH. Global diversity of blackflies (Diptera: Simuliidae) in freshwater. Hydrobiologia, 595: 469-475, 2008.

doi: 10.1007/s10750-007-9114-1 
[2] Araújo-Coutinho CJPC, Nascimento ES, Figueiró R, Becnel JJ. Seasonality and prevalence rates of microsporidia in Simulium pertinax (Diptera: Simuliidae) larvae in the region of Serra dos Órgãos, Rio de Janeiro, Brasil. Journal of Invertebrate Pathology, 85: 188-191, 2004.

doi: $10.1016 /$ j.jip.2004.02.003

[3] Nascimento ES, Figueiró R, Becnel, JJ, Araújo-Coutinho CJPC. Influence of temperature on microsporidia infections in a natural population of Simulium pertinax Kollar, 1832 (Diptera; Simuliidae). Brazilian Journal of Biology, 67: 519-526, 2007.

doi: 10.1590/S1519-69842007000300017

[4] Figueiró R., Araújo-Coutinho CJPC., Gil-Azevedo LH, Nascimento ES, Monteiro RF. Spatial and temporal distribution of blackflies (Diptera: Simuliidae) in the Itatiaia National Park, Brazil. Neotropical Entomology, 35: 542-550, 2006.

doi: 10.1590/S1519-566X2006000400018

[5] Figueiró R, Maia-Herzog M, Gil-Azevedo LH, Monteiro RF. Seasonal variation in black fly (Diptera: Simuliidae) taxocenoses from the Brazilian Savannah (Tocantins, Brasil). Journal of Vector Ecology, 39: 321-327, 2014.

doi: $10.1111 /$ jvec. 12107

[6] Docile TN, Figueiro R, Gil-Azevedo LH, Nessimian JL. Water pollution and distribution of the blackfly (Diptera: Simuliidae) in the Atlantic Forest, Brazil. Revista de Biologia Tropical, 63: 683-693, 2015.

doi: $10.15517 /$ rbt.v63i3.16195

[7] Ciborowski JJH, Craig DA, Fry KM. Dissolved organic matter as a food for black fly larvae (Diptera: Simuliidae). Journal of the North American Benthological Society, 16: 771-780, 1997.

doi: $10.2307 / 1468170$

[8] Malmqvist B, Adler PH, Kuusela K, Merritt RW, Wotton RS. Black flies in the boreal biome, key organisms in both terrestrial and aquatic environments: a review. Écoscience, 11: 187-200, 2004.

doi: 10.1080/11956860.2004.11682824

[9] Figueiró R, Gil-Azevedo LH. The role of the Neotropical blackflies (Diptera: Simuliidae) as vectors of the onchocerciasis: a short overview of the ecology behind the disease. Oecologia Australis, 14: 745-755, 2010.

doi: $10.4257 /$ oeco.2010.1403.10

[10] Figueiró R, Nascimento ES, Gil-Azevedo LH, Maia-Herzog M, Monteiro RF. Local distribution of blackfly (Diptera: Simuliidae) larvae in two adjacent streams: the role of water current velocity in the diversity of blackfly larvae. Revista Brasileira de Entomologia, 52: 452-454, 2008.

doi: 10.1590/S0085-56262008000300020 
[11] Figueiró R, Gil-Azevedo LH, Maia-Herzog M, Monteiro RF. Diversity and microdistribution of black fly (Diptera: Simuliidae) assemblages in the tropical savanna streams of the Brazilian cerrado. Memórias do Instituto Oswaldo Cruz, 107: 362-369, 2012.

doi: 10.1590/S0074-02762012000300011

[12] Levine JM, HilleRisLambers J. The importance of niches for the maintenance of species diversity. Nature, 25: 205-225, 2009.

doi: 10.1038/nature08251

[13] Craig DA, Chance MM. Filter feeding in larvae of Simuliidae (Diptera: Culicomorpha): aspects of functional morphology and hydrodynamics. Canadian Journal of Zoology, 60: 712-724, 1982.

doi: $10.1139 / \mathrm{z} 82-100$

[14] Chance MM, Craig DA. Hydrodynamics and behaviour of Simuliidae larvae (Diptera)Canadian Journal of Zoology, 64: 1295-1309, 1986.

doi: $10.1139 / \mathrm{z} 86-193$

[15] Zhang Y, Malmqvist B. Relationships between labral fan morphology, body size and habitat in North Swedish blackfly larvae (Diptera: Simuliidae). Biological Journal of the Linnean Society, 59: 261-280, 1996.

doi: 10.1111/j.1095-8312.1996.tb01466.x

[16] Zhang Y, Malmqvist B. Phenotypic plasticity in a suspension-feeding insect, Simulium lundstromi (Diptera: Simuliidae), in response to current velocity. Oikos, 78: 503-510, 1997. doi: $10.2307 / 3545611$

[17] Figueiró R, Calvet A, Gil-Azevedo LH, Docile TN, Monteiro RF, Maia-Herzog M. Evidence of phenotypic plasticity of larvae of Simulium subpallidum Lutz in different streams from the Brazilian Cerrado. Revista Brasileira de Entomologia, 59: 30-33, 2015.

doi: 10.1016/j.rbe.2015.02.003

[18] Eaton DP, Diaz LA, Hans-Filho G, Dos Santos V, Aoki V, Friedman H, Rivitti RA, Sampaio SAP, Gottlieb MS, Giudice GJ, Lopez A, Cupp EW. Comparison of black fly species (Diptera: Simuliidae) on an amerindian reservation with a high prevalence of fogo selvagem to neighboring disease free sites in the state of Mato Grosso do Sul, Brazil. Journal of Medical Entomology, 35: 120-131, 1998.

doi: 10.1093/jmedent/35.2.120

[19] Vernal S, Pepinelli M, Casanova C, Goulart TM, Kima O, De Paula NA, Pinto MC, Sá-Nunes A, Roselino AM. Insights into the epidemiological link between biting flies and pemphigus foliaceus in southeastern Brazil. Acta Tropica, 176: 455-462, 2017.

doi: 10.1016/j.actatropica.2017.09.015

Universitas Scientiarum Vol. 26(2):217-227 http://ciencias.javeriana.edu.co/investigacion/universitas-scientiarum 
[20] Coscarón S, Coscarón-Arias CL. Neotropical Simuliidae (Diptera: Insecta)/ Simuliidae Neotropicales (Diptera: Insecta). In: Adis, J., Arias, J. R., Rueda-Delgado, G., Wantzen, K.M. (eds.). Aquatic Biodiversity in Latin America/ Biodiversidad Acuática en América Latina. Vol. 3. Pensoft, Sofia. pp. 1-685, 2007.

[21] Hamada N, Adler PH. Bionomia e chave para imaturos e adultos de Simulium (Diptera: Simuliidae) na Amazônia Central, Brasil. Acta Amazonica, 31: 109-132, 2001.

doi: 10.1590/1809-43922001311132

[22] Liu X, Xu X, Li H. CMEIAS(r): A computer-aided system for the image analysis of bacterial morphotyphes in microbial communities. Microbial Ecology, 41: 173-194, 2001.

doi: $10.1007 / \mathrm{s} 002480000004$

[23] Wilm HG, Storey HC. Velocity head-rod calibrated for measuring streamflow. Civil Engineer, 14: 475-476, 1944.

[24] Lucas P, Hunter FF. Phenotypic plasticity in the labral fan of simuliid larvae (Diptera): effect of seston load on primary-ray number. Canadian Journal of Zoology, 77: 1843-1849, 1999.

doi: 10.1139/cjz-77-12-1843 
Plasticidad fenotípica potencial dentro de las larvas de Simulium nigrimanum Macquart, 1838 (Diptera: Simuliidae)

Resumen: Las larvas de la mosca negra (Diptera: Simuliidae) son filtradoras de material en suspensión que dependen en gran medida de la velocidad del agua para alimentarse adecuadamente. Las especies de mosca negra muestran diferentes preferencias de microhábitat. Los estudios de las larvas de mosca negra del Holártico revelan plasticidad fenotípica en respuesta a las variaciones en la velocidad de la corriente, pero este tipo de estudios raramente se han llevado a cabo con moscas negras del Neotrópico. El presente trabajo presenta resultados acerca de la plasticidad fenotípica de la especie de mosca negra Simulium nigrimanum Macquart. Se fotografiaron 12 larvas en el último instar, muestreadas en el Cerrado brasileño, con estereoscopio-microscopio y se midieron usando el software CMEIAS Image. Se llevaron a cabo regresiones lineales con la velocidad del agua como variable independiente, que indicaron que, mientras el tamaño de cuerpo y el diámetro del disco anal se correlacionaron positivamente con la velocidad del agua, la longitud del abanico labral se correlacionó negativamente. Las relaciones observadas entre la velocidad del agua y la longitud del abanico labral y el diámetro del disco anal fueron consistentes con la literatura, mientras el patrón de variación del tamaño corporal corroboró parcialmente estudios previos. Los resultados del presente trabajo sugieren que se puede observar plasticidad fenotípica potencial en la larva de la mosca negra dentro de una población distribuida en diferentes microhábitats de la misma sección de la corriente, en oposición a reportes previos que implican que tal variación solo se encuentra entre poblaciones de distintas corrientes.

Palabras Clave: mosca negra; abanicos labrales; disco anal; corriente de agua. 
Plasticidade fenotipica potencial de larvas de Simulium nigrimanum Macquart, 1838 (Diptera: Simuliidae)

Resumo: As larvas de borrachudos (Diptera: Simuliidae) são animais filtradores que realizam alimentação em suspensão. Sua ótima alimentação depende da velocidade da água e diferentes espécies preferem diferentes microhabitats. Estudos em borrachudos holoárticos têm mostrado plasticidade fenotípica em relação a mudanças na velocidades da corrente de água. Porém, existem poucos estudos feitos com borrachudos neotropicais. Este trabalho apresenta resultados sobre a plasticidade fenotípica da espécie de borrachudo Simulium nigrimanum Macquart. Doze larvas de último ínstar, amostradas do cerrado brasileiro, foram fotografadas em um estereomicroscópio e medidas usando o software de imagens CEMEIAS. A regressão linear realizada usando velocidade da água como variável independente indicou que o tamanho do corpo e o diámetro do disco anal tinham uma correlação positiva com a velocidade da água. Em contraste, o comprimento dos espiráculos labrais tinham uma correlação negativa com a velocidade da água. As correlações observadas entre velocidade da água e comprimento dos espiráculos labrais e diámetro do disco anal foram consistentes com a literatura. O padrão de variação no tamanho do corpo foi corroborado parcialmente por estudos prévios. Este estudo sugere que uma plasticidade fenotípica potencial pode se observar em larvas de borrachudos dentro de uma população distribuída em diferentes microhabitats da mesma seção de riacho, o que contradiz relatórios prévios que sugerem que esta variação pode ser encontrada unicamente entre populações de diferentes riachos.

Palavras-chave: Borrachudos; espiráculos labrais; disco anal; corrente de água. 
Ronaldo Figueiró He is a Biologist, $\mathrm{MSc}$ and $\mathrm{PhD}$ in Ecology from Universidade Federal do Rio de Janeiro and currently is Adjunt Professor at the Fundação Centro Universitário Estadual da Zona Oeste (UEZO) and is also a lecturer at Centro Universitário de Volta Redonda (UNIFOA). His research focuses on the areas of Ecology and Management of Aquatic Insects and Vectors, with an emphasis on biology, distribution and diversity of Diptera: Simuliidae; Health and Environment, with an emphasis on communicable disease ecology; Science teaching.

ORCID: 0000-0003-0762-1312

Anderson Calvet He is MSc in Biosciences from the Postgraduate Program in Biodiversity and Health at Instituto Oswaldo Cruz with dissertation developed at the Laboratory of Simulidae and Onchocerciasis at Instituto Osvaldo Cruz (LSO/IOC) (concluded in September/2019) . He holds a Bachelor's and Degree in Biological Sciences from Universidade Gama Filho (2010), working in the field of entomology (Diptera, Simuliidae).

ORCID: 0000-0002-7334-7676

Leonardo Henrique Gil-Azevedo He is currently Adjunct Professor at the Department of Entomology at the National Museum of the Federal University of Rio de Janeiro (UFRJ), where he is Curator of the Entomological Collection Collection (MNRJ). Guides master's and doctoral students in the Postgraduate Program in Zoology (MN-UFRJ). Graduated in Biological Sciences from the Federal University of Rio de Janeiro (2003), Masters (2006) and Doctorate (2010) in Biological Sciences (Zoology) from the National Museum - Federal University of Rio de Janeiro. Has experience in Zoology, with emphasis on Taxonomy, Phylogeny, Morphology and Biology of Diptera (Insecta), with emphasis on Simuliidae, Blephariceridae and other aquatic dipterans.

ORCID: 0000-0002-0389-2185

Ricardo Ferreira Monteiro He graduated in Biological Sciences Ecology from the Federal University of Rio de Janeiro (1976), Masters in Ecology from the State University of Campinas (1981) and Ph.D. in Biological Sciences Ecology from the State University of Campinas (1990). He is currently a Collaborating Professor at the Federal University of Rio de Janeiro. Has experience in General Ecology, with an emphasis on Insect Ecology.

ORCID: 0000-0002-5137-9693

Marilza Maia-Herzog She is graduated in Biological Sciences from the Souza Marques Educational Foundation (1978), specialization in Zoological Taxonomy from the Federal University of São Carlos/CNPq; Master's Degree in Veterinary Medicine from the Federal Rural University of Rio de Janeiro (1990) and Ph.D. in Parasitic Biology from the Oswaldo Cruz Foundation (1999). She is a Senior Researcher at Instituto Oswaldo Cruz/Fiocruz.

ORCID: 0000-0002-3914-8833 